\title{
pH Testing as the Primary Method for Nasogastric Tube Placement Verification
}

\author{
Kira Olson*
}

\begin{abstract}
The placement of a nasogastric tube is a standard intervention completed by nurses in the clinical setting. Correct placement of a nasogastric tube is critical for treatment and successful patient outcomes. There are many reasons for nasogastric tube insertion and many methods of placement verification, but the two most common ways of assessing nasogastric tube placement are auscultation and $\mathrm{pH}$ testing. There are advantages and disadvantages to both the auscultation and the $\mathrm{pH}$ testing methods. Evidence from ten studies on nasogastric tube placement in adults was gathered and evaluated to compare and contrast both approaches. The auscultation method is currently the most commonly used in practice. However, the overall research analysis suggests that the $\mathrm{pH}$ testing method is the most accurate and is accompanied by positive patient outcomes. There is still need for further research on this topic as a limited number of studies were analyzed. Study limitations included small sample sizes and were often located outside of Canada, but all studies presented similar evidence in regards to auscultation versus $\mathrm{pH}$ testing. Finally, based on the analysis of the evidence, recommendations are made and barriers to implementation are outlined for practice regarding the application of the $\mathrm{pH}$ method.
\end{abstract}

Keywords: nasogastric, tube, placement, auscultation, pH testing, nursing, recommendations

\section{Background}

Critical thinking skills and knowledge of how to adequately care for patients in a high acuity setting is integral for nursing. Patients in acute care settings usually require a variety of different types of interventions that are focused on symptom management, which is "alleviating symptoms so that the client is able to function at the highest level" (Ackley \& Ladwig, 2014, p.10). Being able to alleviate symptoms requires that nurses be able to accurately assess patients, make clinical decisions, and implement a broad range of skills in the care they provide. This paper will discuss the skill and intervention of nasogastric tubes (NG tube) in the clinical setting, analyze ten articles on this topic to determine which method of placement verification is most reliable for $\mathrm{NG}$ tubes (auscultation or $\mathrm{pH}$ testing), and make recommendations for practice regarding NG tube placement verification.

A common intervention for patients in a high acuity setting is the use of an NG tube. There are a variety of reasons why NG tubes are used, including: decompression of the stomach, removal of stomach contents to prevent aspiration, diminishing nausea and vomiting, and in some

*College of Nursing, University of Saskatchewan, Saskatoon, SK, Canada Correspondence: kmo103@mail.usask.ca 
cases, administering liquids (feed) or medications (Proehl et al., 2011). An important nursing responsibility in caring for and assessing patients with NG tubes is verifying tube placement to prevent the occurrence of life-threatening complications (Proehl et al., 2011; Simons \& Abdallah, 2012). NG tube placement needs to be verified after initial insertion as well as before any feeding or administration of medications because NG tubes can easily become misplaced through "vomiting, coughing, retching, or suctioning [which] can cause the distal tip to migrate upward into the esophagus or downward into the duodenum" (Simons \& Abdallah, 2012, p.40). NG tube misplacement can cause complications such as pneumonia, perforation, aspiration, pneumothorax, and sepsis (Bougault \& Halm, 2009; Simons \& Abdallah, 2012). These complications and changes in illness lead to a delay in discharge and longer hospitalizations for patients, which can cause a reduction in patient outcomes and satisfaction (Kozier, et al., 2014).
There are a variety of methods for checking NG tube placement. These include placing the end of the tube in water and assessing for the absence of bubbling, assessing the appearance of the aspirated gastric contents, and measuring the feeding tube length from the client's nose to the end of the tube and comparing this measurement to the initial insertion length (Bourgault \& Halm, 2009; Simons \& Abdallah, 2012). However, the most commonly used methods in the clinical setting are the auscultation method and $\mathrm{pH}$ method (Preetha, 2009; Simons \& Abdallah, 2012).

The following evidence-based clinical inquiry will analyze and critique the available evidence that examines adults requiring $N G$ tubes, and determine whether injecting air and auscultating over the stomach or aspirating and checking the $\mathrm{pH}$ of the gastric contents is more effective in determining the placement of the NG tube.

Table 1: Definitions and explanation of procedures.

Nasogastric tube- a small tube that is inserted through the nose, down the throat, and goes down into the gastric lumen (Kozier et al., 2014).

Auscultation- listening to sounds within the body through the use of a stethoscope (Jarvis, 2013).

Procedure for the auscultation method- "place a stethoscope over the patient's epigastrium [stomach], and [using a $30 \mathrm{~mL}$ syringe] inject $10 \mathrm{~mL}$ to $30 \mathrm{~mL}$ of air into the tube while listening for a whooshing sound" (Kozier et al., 2014, p.1246).

$\mathrm{pH}$ - "hydrogen ion concentration of the solution [gastric juice]: The higher the hydrogen ion concentration, the lower is the $\mathrm{pH}_{\text {; }}$ the lower the hydrogen ion concentration, the higher is the $\mathrm{pH}^{\prime \prime}$ (Kozier et al., 2014, p.1418).

Procedure for the $\mathrm{pH}$ method- attaching a $30 \mathrm{~mL}$ syringe to the end of the nasogastric tube and "aspirating the stomach contents and checking the $\mathrm{pH}$, which should be acidic... gastric contents are commonly pH 1 to 5 " (Kozier et al., 2014, p.1246).

\section{Methodology}

There is limited research available on the topic of NG tube placement verification. Most sources included systematic reviews of previous articles as well as a collection of outcome data on individuals in hospitals with a nasogastric tube already in place. Studies varied in location, and age and gender often were not specified. Therefore, there is a need for further studies to examine specific populations or age groups (for example, women compared to men or younger ages compared to older). A literature review was conducted using Cumulative Index to Nursing and Allied
Health (CINAHL) and Medline with key phrases and terms such as "adult," "nasogastric," "tube," "gastric," verification," "placement," "methods," "pH," and "auscultation." The analysis of articles included those that discussed nasogastric or gastric tube (which would include nasogastric tubes) placement through the use of $\mathrm{pH}$ testing or auscultation in adults. Articles that left a recommendation as to which method $(\mathrm{pH}$ testing or auscultation) was best practice were preferred. Articles which discussed interventions other than nasogastric tubes such as feeding ostomies- gastrostomy or jejunostomy, placement verification through $\mathrm{x}$-ray, or discussed studies University of Saskatchewan Undegraduate Research Journal 
involving children only were not included in the analysis. Articles were chosen based on the above criteria and were then individually reviewed and analyzed. The articles were broken down based on their level of evidence, purpose/problem, setting, sample/population, $\mathrm{pH}$ testing, comparison (auscultation), findings, and limitations. A table was made from the data that had been analyzed and divided into the above categories for easier comparison purposes (see Appendix A). After each article was individually analyzed, all articles were compared to one another to see which method ( $\mathrm{pH}$ testing or auscultation) was more reliable in verifying nasogastric tube placement in adults. The present study included data from 1950 to 2012.

\section{Results}

Ten studies were identified as being clinically relevant to the topic of nasogastric tube placement. These studies were then analyzed and presented in Appendix A. The level of evidence (presented in Table 2) was used to assess the strength of each study (Howick, 2009). Note that looking at the outcome of $\mathrm{pH}$ testing versus auscultation helps to determine the reliability of each method.

Table 2: Levels of Evidence for Medical Therapies (Howick, 2009).

\begin{tabular}{|c|l|}
\hline Level & Type of Evidence \\
\hline $1 a$ & Systematic review of random control trials (RCTs) \\
\hline $1 b$ & Individual RCT (with narrow confidence intervals) \\
\hline $1 c$ & $\begin{array}{l}\text { All or none studies (e.g., all patients died before a therapy/intervention was available but now some } \\
\text { survive with the therapy/intervention or when some patients died before the therapy/intervention was } \\
\text { made available and now with the therapy/intervention all patients survive) }\end{array}$ \\
\hline $2 a$ & Systematic review (with homogeneity) of cohort studies \\
\hline $2 b$ & Individual cohort study (includes low quality RCT) \\
\hline $2 c$ & Outcomes research and Ecological studies \\
\hline $3 a$ & Systematic review (with homogeneity) of case-control studies \\
\hline $3 b$ & Individual case-control study \\
\hline 4 & Case series and poor quality cohort and case-control studies \\
\hline 5 & $\begin{array}{l}\text { Expert opinion without explicit critical appraisal, or based on physiological bench research or } \\
\text { "first principles" }\end{array}$ \\
\hline
\end{tabular}

\section{Discussion of Results}

The two most commonly used methods for verifying NG tube placement are the auscultation and $\mathrm{pH}$ methods. It is important to determine which method is better because that ensures that best evidence-based practice is being implemented by nurses in the clinical setting and also maintains patient safety. One of the most widely and commonly used methods for verifying NG tube placement is the auscultation method (Preetha, 2009). The auscultation method is viewed as being favorable in verifying NG tube placement because it is easy, time efficient, cost effective, and can be quickly performed by the nurse at the bedside (Preetha, 2009). The auscultation method does not require a variety of supplies as compared to the $\mathrm{pH}$ testing method (i.e., $\mathrm{pH}$ indicator paper or $\mathrm{pH}$ meters) which can save the health care system unnecessary expenditures. However, a major downfall to this method is that it has been shown to be inaccurate and unreliable at identifying correct NG tube placement in a variety of studies (Bourgault \& Halm, 2009; Proehl et al., 2011; Simons \& Abdallah, 2012; Taylor \& Clemente, 2005). Often, the "whooshing sound" heard with the auscultation method can be heard with correct and incorrect placement (Simons \& Abdallah, 2012). These results indicate a strong correlation with a higher risk for complications such as aspiration and perforation and were associated with a number of recorded deaths attributed to misplaced NG tubes (Simons \& Abdallah, 2012; Taylor \& Clemente, 2005). Due to these key downfalls, there were no studies in the review of the literature that supported the use of the auscultation method for NG tube placement verification. In many of the studies examined there was a reoccurring argument that this method should be discouraged and 
discontinued (Boeykens et al., 2014; Bourgault and Halm, 2009; Simons \& Abdallah, 2012; Taylor \& Clemente, 2005). The discontinuation of the auscultation method would lead to correct verification of NG tube placement, decreased patient complications, and increased patient outcomes. Therefore, auscultation, the current method of NG tube verification, should be improved and reassessed as to whether this method is the safest for patients and the most evidence-based method for the acute care setting.

The other commonly used method in NG tube verification is the $\mathrm{pH}$ method (Simons \& Abdallah, 2012). A major strength of this method is that it has a higher sensitivity and specificity for accurately determining correct NG placement than auscultation (Boeykens et al., 2014i Preetha, 2009; Simons 2012; Turgay \& Khorshid, 2010). This method is more reliable in its ability to accurately distinguish between gastric, intestinal, or respiratory placement (Simons \& Abdallah, 2012). Therefore, the $\mathrm{pH}$ method is more accurate at identifying the placement of NG tubes (Boeykens et al., 2014; Bourgault \& Halm, 2009; Ellet, 2004; Metheny \& Meert, 2004; Proehl et al., 2011; Simons \& Abdallah, 2012; Taylor \& Clemente, 2005). When testing the gastric $\mathrm{pH}$ using the $\mathrm{pH}$ method, it is important to have a $30 \mathrm{~mL}$ syringe to aspirate the gastric contents. There is a range of recommended values for $\mathrm{pH}$ that detects where the NG tube is placed. A pH less than or equal to 5.5 indicates the NG tube is placed in the stomach (Boeykens et al., 2014; Fernandez et al., 2010; Kozier et al., 2014). A pH of 6 or higher usually indicates NG placement in the respiratory tract, pleural space, or intestinal tract (Boeykens et al., 2014; Kozier et al., 2014). Simons and Abdallah (2012) stated that this method is accurate, simple, and efficient for nurses in the clinical setting and for distinguishing between correct and incorrect NG tube placements.

However, there are significant disadvantages associated with the $\mathrm{pH}$ method. Accuracy of NG tube placement can be altered through the use of medications such as proton pump inhibitors and $\mathrm{H}_{2}$-receptor blockers because these medications can alter the $\mathrm{pH}$ of the stomach and lead to higher pH levels (Simons \& Abdallah, 2012; Fernandez, Chau, Thompson, Griffiths, \& Lo, 2010; Bourgault \& Halm, 2009; Ellet, 2004; Boeykens et al., 2014; Taylor \& Clemente, 2005; Turgay \& Khorshid, 2010). Another downfall to this method is when patients are on continuous feeds through the NG tubes because NG feedings can alter the $\mathrm{pH}$ of the stomach and cause inaccurate $\mathrm{pH}$ readings leading to difficulties determining correct NG tube placement (Boeykens et al., 2014; Simons \& Abdallah, 2012). The $\mathrm{pH}$ method is also seen as being costly when compared to the auscultation method because of the cost of $\mathrm{pH}$ indicator paper and $\mathrm{pH}$ meters (Preetha, 2009). These weaknesses are minor compared to the vast number of complications that can occur from the incorrect placement by using the auscultation method (e.g., pneumonia, perforation, aspiration, pneumothorax, and sepsis which can lead to longer hospitalizations (Bougault \& Halm, 2009; Simons \& Abdallah, 2012)). In reviewing the literature, studies were consistent with one another in coming to the conclusion that the $\mathrm{pH}$ method is accurate and reliable in determining correct NG tube placement. This is especially true when being compared to the auscultation method; therefore, the $\mathrm{pH}$ method is very well supported by all of the studies analyzed (Boeykens et al., 2014; Bourgault \& Halm, 2009; Ellet, 2004; Fernandez et al., 2010; Metheny \& Meert, 2004; Preetha, 2009; Proehl et al., 2011; Simons \& Abdallah, 2012; Taylor \& Clemente, 2005; Turgay \& Khorshid, 2010). Further research on this topic is needed, such as additional research looking at the different NG tube placement verification methods, research on specific $\mathrm{pH}$ values and what placement is associated with those values, and research on interventions such as feeds or medications like proton pump inhibitors and $\mathrm{H} 2$-receptor blockers and what $\mathrm{pH}$ value can be associated with correct placement when a patient is receiving these interventions. However, the preliminary evidence in the articles analyzed suggests that $\mathrm{pH}$ testing for $\mathrm{NG}$ tube placement verification is the more accurate and reliable method (Boeykens et al., 2014; Bourgault \& Halm, 2009; Ellet, 2004; Metheny \& Meert, 2004; Proehl et al., 2011; Simons \& Abdallah, 2012; Taylor \& Clemente, 2005). See Appendix 1.

\section{Limitations}

There is limited research that specifically discusses nasogastric tube placement verification using $\mathrm{pH}$ testing and auscultation. In the present study, there were a small number of studies analyzed and varied in regards to time frames, locations, and sample sizes. Making it difficult to perform a homogeneous analysis of the articles. Other limitations indicate the reliability of the $\mathrm{pH}$ testing method include whether feeding infusions are continuous or bolus and whether acid inhibitor medications are being used by the patient (Fernandez et al., 2010). Since NG tube insertion is unpleasant, uncomfortable, and can cause distress (Kozier et al., 2014), it is difficult and unethical to have a control group; therefore, there were no articles available that included randomized control trials (the strongest level of evidence). Small sample sizes were a common limitation in the reviewed studies, and often consisted of opportunity population of individuals who had already had an NG tube in place (Preetha, 2009; Taylor \& Clemente, 2005; Turgay \& Khorshid, 2010). Finally, many of the articles assessed were based out of the United States or other countries and not based in Canada. 


\section{Summary and Recommendations for Practice}

Based on the review of the literature, the auscultation method for verification of NG tube placement is not well supported; however, it is still a commonly used method in clinical practice (Proehl et al., 2011; Saskatoon Health Region, 2013; Simons \& Abdallah, 2012). Therefore, a recommendation for practice would include using the $\mathrm{pH}$ method instead of the auscultation method for verification of NG tube placement to ensure accuracy and reliability and help reduce complications and improve patient outcomes. This method can help to ensure safe practice and correct feeding and medication administration (Fernandez et al., 2010). Implementation of the $\mathrm{pH}$ method in Saskatoon would require an analysis of current policies and procedures regarding NG tubes in the Saskatoon Health Region's policies. These policies would need to be analyzed to ensure that they are up-to-date and follow best practice of using the $\mathrm{pH}$ method instead of auscultation. The implementation of the $\mathrm{pH}$ method may also require close monitoring of nursing practice to ensure that NG tube placements are being confirmed with the use of the most accurate evidence-based practice, and that adverse effects from inaccurate NG tube placement confirmation are reported (Bourgault \& Halm, 2009). The implementation process would also require accurate resources and supplies such as $\mathrm{pH}$ indicator paper and $\mathrm{pH}$ meters to be available on the unit so that nurses have immediate access to these supplies. Implementation can also be enhanced through educational programs and by providing information that is focused on the $\mathrm{pH}$ method and its levels of accuracy and reliability to enhance nursing knowledge and attitudes towards this method (Gesme \& Wiseman, 2010). Other important aspects in program implementation would include demonstrations for staff, effective leadership, communication, a shared vision for evidence-based change, and collaboration among team members (Gesme \& Wiseman, 2010). This can help nurses feel supported and encouraged. However, there are barriers to the implementation of new skills, such as negative attitudes, unwillingness to change, and the challenge of breaking old habits (Gesme \& Wiseman, 2010; Simons \& Abdallah, 2012). The implementation of the $\mathrm{pH}$ method for verification of NG tube placement may be costly, as this technique requires the use of $\mathrm{pH}$ indicator paper for verification (Preetha, 2009) which may act as a barrier to the implementation of this method. Short term goals for the implementation of the $\mathrm{pH}$ method include educating nurses as to why auscultation is not an effective method for determining NG tube placement, and the risks associated with it, and encouraging communication and collaboration between nurses. A long-term goal could include the revision of hospital policies to reflect evidence-based practice through the removal of the auscultation method and the implementation of the $\mathrm{pH}$ method to enhance patient outcomes and decrease patient complications from inaccurate NG tube placement (Bourgault \& Halm, 2009). Overall, through the analysis of these articles, there was strong evidence to support the use of the $\mathrm{pH}$ method for determining NG tube placement and little support for the use of the auscultation method.

\section{References}

Ackley, B. J., \& Ladwig, G. B. (2014). Nursing diagnosis handbook: An evidence-based guide to planning care (1oth ed.). St. Louis, MO: Mosby Elsevier.

Boeykens, K., Steeman, E., \& Duysburgh, I. (2014). Reliability of $\mathrm{pH}$ measurement and the auscultatory method to confirm the position of a nasogastric tube. International Journal of Nursing Studies, 51, 1427-1433. doi:10.1016/j.ijnurstu.2014.03.004

Bourgault, A., \& Halm, M. (2009). Feeding tube placement in adults: Safe verification method for blindly inserted tubes. American Journal Of Critical Care, 18(1), 73-76. doi:10.4037/ajcc2009911

Ellett, M. (2004). What is known about methods of correctly placing gastric tubes in adults and children. Gastroenterology Nursing, 27(6), 253-261. doi: 10.1097/00001610-200411000-00002

Fernandez, R., Chau, J., Thompson, D., Griffiths, R., \& Lo, H. (2010). Accuracy of biochemical markers for predicting nasogastric tube placement in adults- A systematic review of diagnostic studies. International Journal of Nursing Studies, 47(8), 1037-1046. doi:10.1016/j.ijnurstu. 2010.03.015

Gesme, G., \& Wiseman, M. (2010). How to implement change in practice. Journal of Oncology Practice, 6(5), 257-259. doi: 10.1200/JOP.000089

Howick, J. (2009). Oxford Center for Evidence-based Medicine-Levels of Evidence. Retrieved from http://www.cebm.net/oxford-centre-evidence-basedmedicine-levels-evidence-march-2009/

Jarvis, C. (2013). Physical examination \& health assessment (2nd ed.). Toronto, ON: Saunders Elsevier.

Kozier, B., Erb, G., Berman, A., Snyder, S. J., Buck, M., Yiu, L., \& Stampler, L. L. (2014). Fundamentals of Canadian 
nursing: Concepts, process, and practice. Toronto, ON: Pearson Education.

Metheny, N., \& Meert, K. (2004). Monitoring feeding tube placement. Nutrition In Clinical Practice, 19(5), 487-495. doi: 10.1177/0115426504019005487

Preetha, K. (2009). Effectiveness of auscultation and testing $\mathrm{pH}$ for assessing the placement of feeding tube. Nursing Journal Of India, 100(5), 112-114. Retrieved from http://crawl.prod.proquest.com.s3.amazonaws.com/fpc ache/5ob8acbaoo76ed27obfc6e8c96oe6577.pdf?AWSAc cessKeyld=AKIAJF7V7KNV2KKY2NUQ\&Expires $=147699$ 9773\&Signature $=O \mathrm{ObbPhpY}_{5} 6$ u48sJG $_{5}$ rKJJlobvZiM\%3D

Proehl, J. A., Heaton, K., Naccarato, M. K., Crowley, M. A., Storer, A., Moretz, J. D., \& Li, S. (2011). Emergency nursing resource: Gastric tube placement verification. JEN: Journal Of Emergency Nursing, 37(4), 357-362. doi:10.1016/j.jen.2011.04.011

Saskatoon Health Region. (2013). Policy and procedure manual: Nasogastric/Orogastric tube: Insertion, care of, and removal-1040. Retrieved from https://www.saskatoonhealthregion.ca/about/NursingM anual/1040.pdf

Simons, S. R., \& Abdallah, L. M. (2012). Bedside assessment of enteral tube placement: Aligning practice with evidence. American Journal Of Nursing, 112(2), 40-48. doi: 10.1097/01.NAJ.0000411178.07179.68

Taylor, S., \& Clemente, R. (2005). Confirmation of nasogastric tube position by $\mathrm{pH}$ testing. Journal of Human Nutrition \& Dietetics, 18(5), 371-375. doi: 10.1111/j.1365-277X.2005.00635.X

Turgay, A., \& Khorshid, L. (2010). Effectiveness of the auscultatory and $\mathrm{pH}$ methods in predicting feeding tube placement. Journal Of Clinical Nursing, 19(11-12), 15531559. doi:10.1111/j.1365-2702.2010.03191.x 


\section{Appendix A \\ Analysis of Sources with the Level of Evidence}

Table A1: Boeykens et al., 2014.

\begin{tabular}{|c|c|}
\hline Level of Evidence & $3 b$ \\
\hline Research Design & $\begin{array}{l}\text {-Large prospective observational study } \\
-270 \text { used } \mathrm{pH} \text { measurement } \\
-301 \text { had the auscultation method done after X-ray confirmation from a total of } 331 \text { tubes. }\end{array}$ \\
\hline Problem/Purpose & $\begin{array}{l}\text {-Evaluate the auscultatory method and } \mathrm{pH} \text { method with a measurement cut off of } 5.5 \text { after tube } \\
\text { insertion and to compare this with the gold standard: an abdominal X-ray. }\end{array}$ \\
\hline Setting & -General hospitals in Belgium from September 2009 to December 2012 \\
\hline Sample/Population & $\begin{array}{l}-331 \text { tubes inserted into } 314 \text { patients } \\
\text {-Average age of } 69 \text { years old and mostly male }\end{array}$ \\
\hline pH Testing & $\begin{array}{l}\text {-Without the use of antacids the } \mathrm{pH} \text { was } 3.5 \text { in the stomach. } \\
\text {-With the use of antacids the average gastric } \mathrm{pH} \text { was } 4.6 \text {. } \\
\text {-In } 270 \mathrm{pH} \text { measurements ( } 241 \text { could be compared to } \text {-ray) there was a } \mathrm{pH} \text { of less than or equal } \\
\text { to } 5.5 \text { and this method was accurate } 98.9 \% \text { of the time in determining } \mathrm{NG} \text { tube location in the } \\
\text { stomach. } \\
\text {-Overall, the } \mathrm{pH} \text { was able to show that the NG tube was correctly placed in the stomach } 78.4 \% \\
\text { of the time and the } \mathrm{pH} \text { method was able to tell that the NG tube was not placed in the stomach } \\
84.6 \% \text { of the time. }\end{array}$ \\
\hline Comparison & $\begin{array}{l}\text {-The auscultation method was used in } 301 \text { individuals after x-ray confirmation and was able to } \\
\text { tell the NG tube was correctly placed in the stomach } 79 \% \text { of the time and that the NG tube was } \\
\text { not in the stomach } 61 \% \text { of the time. }\end{array}$ \\
\hline Findings & $\begin{array}{l}\text {-The auscultatory method may identify tube placement but it is not an accurate way to detect if } \\
\text { the NG tube is outside of the stomach. } \\
\text {-The whooshing sounds in the auscultatory method can have different interpretations and lead } \\
\text { to wrong judgments of NG tube placement, therefore this method is discouraged. } \\
\text { The pH method using a pH cut off of less than or equal to } 5 \cdot 5 \text { is a reliable method to identify NG } \\
\text { tube placement in the stomach compared to other methods. }\end{array}$ \\
\hline Limitations & -Based out of Belgium \\
\hline
\end{tabular}

Table A2: Bourgault \& Halm, 2009.

\begin{tabular}{|l|l|}
\hline Level of Evidence & $2 a$ \\
\hline Research Design & -Systematic review of 12 studies published between 1988 and 2007 \\
\hline Problem/Purpose & -Determine the accuracy of methods to verify initial feeding tube placement after blind insertion \\
\hline Setting & -Acute/intermediate care and intensive care settings \\
\hline Sample/Population & $\begin{array}{l}\text {-Adults with feeding tubes } \\
\text {-Sample sizes ranged from } 51 \text {-880 }\end{array}$ \\
\hline pH Testing & $\begin{array}{l}\text {-pH less than } 5 \text {-0 indicates NG placement in the stomach } \\
\text {-This may not be helpful in detecting esophageal placement because of gastric reflux } \\
\text {-This method may be difficult to use when assessing NG placement in people receiving H2 } \\
\text { blockers or continuous feeding }\end{array}$ \\
\hline
\end{tabular}




\begin{tabular}{|l|l|}
\hline Comparison & $\begin{array}{l}\text {-For auscultation, many studies had audible air entry over the epigastrium even when the tube } \\
\text { was malpositioned therefore this method is not reliable }\end{array}$ \\
\hline Findings & $\begin{array}{l}\text {-Auscultation to check tube placement should be discontinued because of its lack of efficacy } \\
\text { and increased risk for harm to the patient } \\
\text {-Best way to identify insertion is through radiography } \\
-p H \text { method can be used for ongoing assessment at the bedside }\end{array}$ \\
\hline Limitations & $\begin{array}{l}\text {-Based on initial insertion of feeding tubes only } \\
\text {-Article is based out of the United States } \\
\text {-Size of the systematic review was small (only 12 studies) and specific setting (country/city) was } \\
\text { not given } \\
\text {-This article is more than } 5 \text { years old }\end{array}$ \\
\hline
\end{tabular}

Table A3: Ellet, 2004.

\begin{tabular}{|c|c|}
\hline Level of Evidence & $2 a$ \\
\hline Research Design & -Literature review of an unknown number of studies \\
\hline Problem/Purpose & $\begin{array}{l}\text {-To find information about the different types of gastric tube placement methods and } \\
\text { determine which method is best at determining GT placement in adults and children }\end{array}$ \\
\hline Setting & -not stated in article \\
\hline Sample/Population & -Adults and children that had gastric tubes placed for short term feeding \\
\hline pH Testing & $\begin{array}{l}\text {-pH method is better at detecting over auscultation because of the different } \mathrm{pH} \text { in different } \\
\text { tissues. } \\
\text {-pH testing alone is seen to be an inadequate indicator of GT placement because of factors such } \\
\text { as overlap pH between sites and difficulties with aspiration. } \\
\text {-The use of acid-inhibiting medications can limit the usefulness of this method. }\end{array}$ \\
\hline Comparison & $\begin{array}{l}\text {-The auscultation method should not be used because it is not reliable at detecting } \\
\text { mispositioning in the respiratory system. }\end{array}$ \\
\hline Findings & $\begin{array}{l}\text {-Overall, } \mathrm{pH} \text { is a promising method for determination tube position. } \\
\text {-pH of less than or equal to } 5 \text { is able to differentiate between gastric and esophageal and } \\
\text { intestinal placements but a } \mathrm{pH} \text { greater then } 5 \text { cannot differentiate between intestinal, } \\
\text { esophageal, and gastric placements and may need a second method (abdominal radiograph) to } \\
\text { determine tube location. }\end{array}$ \\
\hline Limitations & $\begin{array}{l}\text {-The article is from } 2004 \text {, therefore articles cited are old. } \\
\text {-Narrowed to small-bore nasogastric and orogastric tubes under the umbrella term of gastric } \\
\text { tubes (GT). } \\
\text {-A setting was not given in this study. } \\
\text {-Sample size/range from the studies analyzed was not made specific. }\end{array}$ \\
\hline
\end{tabular}

Table A4: Fernandez et al., 2010.

\begin{tabular}{|l|l|}
\hline Level of Evidence & $2 \mathrm{a}$ \\
\hline Research Design & -Systematic review of 10 studies from 1950-2008 from online databases \\
\hline Problem/Purpose & $\begin{array}{l}\text {-Investigate the diagnostic performance of biochemical tests used to determine placement of } \\
\text { NG tubes after insertion in adults }\end{array}$ \\
\hline Setting & -Acute care facilities in the USA \\
\hline
\end{tabular}




\begin{tabular}{|c|c|}
\hline Sample/Population & $\begin{array}{l}\text {-NG tube placements in adults } \\
\text {-Sample sizes in the } 10 \text { studies ranged from 36-89o. }\end{array}$ \\
\hline pH Testing & $\begin{array}{l}\text { - } \mathrm{pH} \text { value of less than or equal to } 5 \cdot 5 \text { has a greater ability to determine gastric placement of the } \\
\mathrm{NG} \text { tube. } \\
\text { - } \mathrm{pH} \text { can be varied because of antacid medications. }\end{array}$ \\
\hline Comparison & -not stated in article \\
\hline Findings & $\begin{array}{l}\text {-This study has insufficient evidence to be able to determine the optimal cut-off pH value to } \\
\text { differentiate between gastric and intestinal placements. } \\
\text {-Use of a pH of less than or equal to } 5.5 \text { has led to higher detection of tubes in the gastric and/or } \\
\text { intestinal areas. } \\
\text {-This method is more reliable than auscultation in determining NG placements. }\end{array}$ \\
\hline Limitations & $\begin{array}{l}\text {-This study is based out of the United States. } \\
\text {-This study did not examine the effectiveness and reliability of auscultation for NG tube } \\
\text { placement and only focused on } \mathrm{pH} \text {. } \\
\text {-Studies analyzed in the systematic review were very similar. } \\
\text {-This study does not include NG misplacement in the respiratory tract. }\end{array}$ \\
\hline
\end{tabular}

Table A5: Metheny \& Meert, 2004.

\begin{tabular}{|c|c|}
\hline Level of Evidence & 5 \\
\hline Research Design & $\begin{array}{l}\text {-Literature review on an unknown number of studies leading to a mix of research based and } \\
\text { opinion based discussion }\end{array}$ \\
\hline Problem/Purpose & $\begin{array}{l}\text {-To describe currently available bedside methods to determine feeding tube placement after } \\
\text { initial insertion and once tube feedings have been started } \\
\text {-Review information about clinically available bedside methods to predict feeding tube location }\end{array}$ \\
\hline Setting & -not stated in article \\
\hline Sample/Population & -Individuals with feeding tubes \\
\hline pH Testing & $\begin{array}{l}\text {-pH testing is helpful in differentiating between gastric, intestinal, and respiratory placement } \\
\text { when gastric } \mathrm{pH} \text { is low. } \\
\text { - } \mathrm{pH} \text { of } 0-4 \text { indicates gastric placement. } \\
\text { - Respiratory secretions do not have a } \mathrm{pH} \text { less than } 6 \text {, while intestinal secretions have a } \mathrm{pH} \\
\text { greater or equal to } 7 \text {, allowing a } \mathrm{pH} \text { of } 0-4 \text { in the stomach to be an effective predictor of gastric } \\
\text { placement. } \\
\text {-When gastric } \mathrm{pH} \text { is } 6 \text { or greater this method is not useful because it is too difficult to } \\
\text { differentiate from gastric and respiratory placement. } \\
\text {-A change in } \mathrm{pH} \text { is a useful indicator of tube movement. }\end{array}$ \\
\hline Comparison & $\begin{array}{l}\text {-The auscultation method has been used for many years but is questioned for accuracy and } \\
\text { reliability. } \\
\text {-No evidence available that states this method can rule out respiratory placement. } \\
\text {-The efficacy of this method in determining between gastric and intestinal placement has not } \\
\text { been done under controlled conditions therefore, it has little evidence to support its reliability. }\end{array}$ \\
\hline Findings & $\begin{array}{l}\text {-Auscultation is not effective (on its own or combined) in determining tube placement. } \\
\text {-The } \mathrm{pH} \text { method can be useful in combination with other methods for checking tube } \\
\text { placement. }\end{array}$ \\
\hline Limitations & $\begin{array}{l}\text {-The article is from } 2004 \text {, therefore articles referenced are old. } \\
\text {-Setting and specific sample sizes were not given. }\end{array}$ \\
\hline
\end{tabular}


Table A6: Preetha, 2009.

\begin{tabular}{|c|c|}
\hline Level of Evidence & $3 b$ \\
\hline Research Design & -A comparative and evaluative search approach \\
\hline Problem/Purpose & $\begin{array}{l}\text {-Determine the effectiveness of auscultation and testing } \mathrm{pH} \text { for assessing the placement of } \\
\text { feeding tubes. }\end{array}$ \\
\hline Setting & -P. S. Medical Centre in Kanya-kumari district of India over a one month period \\
\hline Sample/Population & $\begin{array}{l}-50 \text { adult subjects with feedings tubes } \\
- \text { Ages ranged from } 30-70 \text { years old } \\
-56 \% \text { were males and } 44 \% \text { were females }\end{array}$ \\
\hline pH Testing & $\begin{array}{l}\text {-All } 50 \text { subjects had aspirate checked. } \\
\text { - } \mathrm{pH}<5 \text { is considered gastric placement and a pH of }>6 \text { was considered an intestinal placement. } \\
\text {-This method stated that } 90 \% \text { of the } \mathrm{NG} \text { tubes had gastric placement and } 10 \% \text { of the NG tubes } \\
\text { were misplaced, which was proven to be correct when compared to the X-ray. }\end{array}$ \\
\hline Comparison & $\begin{array}{l}\text {-All } 50 \text { subjects had auscultation checked. } \\
\text {-Whooshing sound heard over the epigastric area was considered a gastric placement. } \\
\text {-With this method it stated that } 96 \% \text { of subjects had gastric placement and } 4 \% \text { had intestinal } \\
\text { placement, when this was compared to X-ray it was stated that } 90 \% \text { of the tubes were placed in } \\
\text { the stomach and } 10 \% \text { of the tubes were misplaced. }\end{array}$ \\
\hline Findings & $\begin{array}{l}\text {-pH testing is more reliable and accurate compared to the auscultation method when assessing } \\
\text { NG tube placement. }\end{array}$ \\
\hline Limitations & $\begin{array}{l}\text {-Study is out of India } \\
\text {-Small sample size } \\
\text {-This article is more than } 5 \text { years old }\end{array}$ \\
\hline
\end{tabular}

Table A7: Proehl et al., 2011.

\begin{tabular}{|c|c|}
\hline Level of Evidence & $2 a$ \\
\hline Research Design & -Systematic review of an unknown number of studies between 1994 to October 2010 \\
\hline Problem/Purpose & $\begin{array}{l}\text {-Evaluation of various bedside gastric tube placement verification methods as an alternate to } \\
\text { radiography }\end{array}$ \\
\hline Setting & -A variety of English language articles from a variety of settings \\
\hline Sample/Population & -Patients with gastric tubes inserted \\
\hline $\mathrm{pH}$ Testing & $\begin{array}{l}\text {-pH value less than } 3.9 \text { to } 7 \text { to differentiate placement in the stomach versus the pulmonary } \\
\text { system. } \\
\text {-pH can be influenced by feedings and acid suppressing medications. } \\
\text {-Reliability of this method ranges from } 84 \% \text { to } 97 \% \text {. }\end{array}$ \\
\hline Comparison & $\begin{array}{l}\text { - Instillation of air into the tube while listening over the epigastric region with a stethoscope for } \\
\text { a whooshing sound } \\
\text {-Unreliable as a single verification method } \\
\text {-Most common method used by nurses }\end{array}$ \\
\hline Findings & $\begin{array}{l}\text {-GT placement verification methods are more accurate when combined. } \\
\text {-Auscultation cannot be a verification method for placement on its own because it is unreliable. } \\
\text {-The pH method can be used as a component of a multiple method verification approach. }\end{array}$ \\
\hline Limitations & $\begin{array}{l}\text {-Examines nasogastric and orogastric tubes under the umbrella term gastric tubes (GT). } \\
\text {-A specific sample size/range was not given. }\end{array}$ \\
\hline
\end{tabular}


-Setting was not specific to a certain area (city/country) or facility.

Table A8: Simons \& Abdallah, 2012.

\begin{tabular}{|c|c|}
\hline Level of Evidence & $2 a$ \\
\hline Research Design & $\begin{array}{l}\text {-Systematic review of nursing literature published between 1980-2010 from a variety of } \\
\text { databases ( } 20 \text { research articles), including } 20 \text { nursing textbooks published between 2002-2010 } \\
\text { and } 28 \text { hospital policies }\end{array}$ \\
\hline Problem/Purpose & $\begin{array}{l}\text { - Assess and evaluate the various methods for assessing enteral feeding tube placement and } \\
\text { make an evidence-based practice recommendation based on the reliability of each method }\end{array}$ \\
\hline Setting & -not stated in article \\
\hline Sample/Population & $\begin{array}{l}\text {-Online review of nursing literature } \\
\text {-Convenience sample of hospital and skilled nursing facility policies from Massachusetts and } \\
\text { New Hampshire for assessing enteral feeding tube placement ( } 28 \text { in total) }\end{array}$ \\
\hline $\mathrm{pH}$ Testing & $\begin{array}{l}\text {-pH of } 1-4 \text { indicates the NG tube is in the stomach. } \\
\text {-Easy method that can distinguish between gastric and intestinal placement. } \\
\text {-Many studies support this method but it is not always reliable. }\end{array}$ \\
\hline Comparison & $\begin{array}{l}\text {-Auscultation is a commonly used method that has been proven to be ineffective in } \\
\text { determining NG tube placement and can cause significant harm to patients. } \\
\text { - This method is seen as highly unreliable because a whooshing sound can still be heard even if } \\
\text { the tube is incorrectly placed in the lung. }\end{array}$ \\
\hline Findings & $\begin{array}{l}\text {-Methods should be used in combination for checking NG placement (e.g., visually assessing } \\
\text { aspirate and checking } \mathrm{pH} \text { ). } \\
\text {-If an X-ray has confirmed initial tube placements, bedside methods for assessing NG } \\
\text { placement could include a variety of options including aspirating and checking } \mathrm{pH} \text {, but not } \\
\text { including auscultation and listening for air over the epigastrium, since this method is } \\
\text { ineffective. } \\
\text {-pH can be altered by the use of medications such as PPIs and } \mathrm{H} 2 \text { receptor blockers and feeding } \\
\text { tube preparations can be more alkaline. }\end{array}$ \\
\hline Limitations & $\begin{array}{l}\text {-Study based out of the United States } \\
\text {-A specific sample or sample range from the studies analyzed were not given. }\end{array}$ \\
\hline
\end{tabular}

Table A9: Taylor \& Clemente, 2005.

\begin{tabular}{|c|c|}
\hline Level of Evidence & $3 b$ \\
\hline Research Design & $\begin{array}{l}\text {-One day cross-sectional survey of all patients requiring NG tube placement checks, followed by } \\
\text { an observational study to assess the accuracy of pH strip testing for NG tube placement }\end{array}$ \\
\hline Problem/Purpose & $\begin{array}{l}\text {-To assess currently used NG tube placement methods and assess their safety and efficacy for } \\
\text { confirming tube placement } \\
\text {-Determining NG tube placement accuracy and methods in relation to the use of } \mathrm{H} \text {-receptor } \\
\text { blockers and PPIs }\end{array}$ \\
\hline Setting & -Hospitals \\
\hline Sample/Population & $\begin{array}{l}-52 \text { patients required NG and nasointestinal (NI) feedings } \\
\text {-It was not stated what number of patients were tested with } \mathrm{pH} \text { vs. auscultation. Nurses were } \\
\text { asked which method was used or charts were checked as to which method was used. }\end{array}$ \\
\hline pH Testing & - $\mathrm{pH}$ testing is the first line confirmation technique for NG placement. \\
\hline
\end{tabular}




\begin{tabular}{|l|l|}
\hline Comparison & $\begin{array}{l}\text {-Auscultation method is unlikely to warn of improper tube placement. } \\
\text {-This method should be discontinued }\end{array}$ \\
\hline Findings & $\begin{array}{l}\text {-Large surveys and trials on the efficacy and accuracy of } \mathrm{pH} \text { testing are still required. } \\
\text {-Many factors can alter } \mathrm{pH}(\mathrm{PPIs}, \mathrm{H} 2 \text { blockers). } \\
\text { - } \mathrm{pH} \text { testing is a more safe and reliable method than other methods such as auscultation. } \\
\text {-Use of } \mathrm{pH} \text { in determining confirmation of } \mathrm{NG} \text { tube positioning is imperative. } \\
\text {-X-ray is still the gold standard. }\end{array}$ \\
\hline Limitations & - The article is from 2005, therefore articles referenced are old. \\
& - Small sample size \\
& - Setting is not specific as to where (city/country) the study took place
\end{tabular}

Table A10: Turgay \& Khorshid, 2010.

\begin{tabular}{|c|c|}
\hline Level of Evidence & $3 b$ \\
\hline Research Design & -A prospective observational study \\
\hline Problem/Purpose & $\begin{array}{l}\text {-To determine the effectiveness of the auscultatory and } \mathrm{pH} \text { methods in predicting feeding tube } \\
\text { location in critically ill patients }\end{array}$ \\
\hline Setting & ICU in Turkey \\
\hline Sample/Population & -44 newly inserted feeding tubes in 32 critically ill adult patients ranging in age from $38-87$ years \\
\hline pH Testing & $\begin{array}{l}\text {-Before checking } \mathrm{pH}, 30 \mathrm{~mL} \text { of air was insufflated into the tube to ensure that no formula or } \\
\text { medications were in the tube so that a more accurate } \mathrm{pH} \text { could be obtained. } \\
\text { - } 88.6 \% \text { of the gastric aspirates had a } \mathrm{pH} \text { value }<6 \text {. } \\
-39 \text { of the } 44 \text { tubes were able to be predicted as the correct placement via the } \mathrm{pH} \text { method, } \\
\text { whereas the other } 5 \text { were able to be determined as incorrect by the } \mathrm{pH} \text { method. } \\
\text { - } \mathrm{pH} \text { method was most accurate with the radiological readings. }\end{array}$ \\
\hline Comparison & $\begin{array}{l}-40 \text { of the } 44 \text { tubes inserted were said to be correct with the auscultation method, and } 4 \text { tubes } \\
\text { were said to be incorrect, which does not agree with the radiological readings of } 39 \text { and } 5 \text {. }\end{array}$ \\
\hline Findings & $\begin{array}{l}\text {-The mean pH readings were found to be } 4.2 \text {. } \\
\text {-Several factors can affect gastric } \mathrm{pH} \text { such as } \mathrm{H} 2 \text { receptor agonists and PPIs. } \\
\text {-The auscultatory method should not be used as the only method to determine NG tube } \\
\text { placement and rule out respiratory positioning of inserted NG tubes. } \\
\text {-Overall, the } \mathrm{pH} \text { method is most effective in determining the feeding tube position. }\end{array}$ \\
\hline Limitations & $\begin{array}{l}\text {-Small sample size } \\
\text {-Setting in Turkey }\end{array}$ \\
\hline
\end{tabular}




\section{Appendix B}

Decision Making Aid in the Clinical Setting

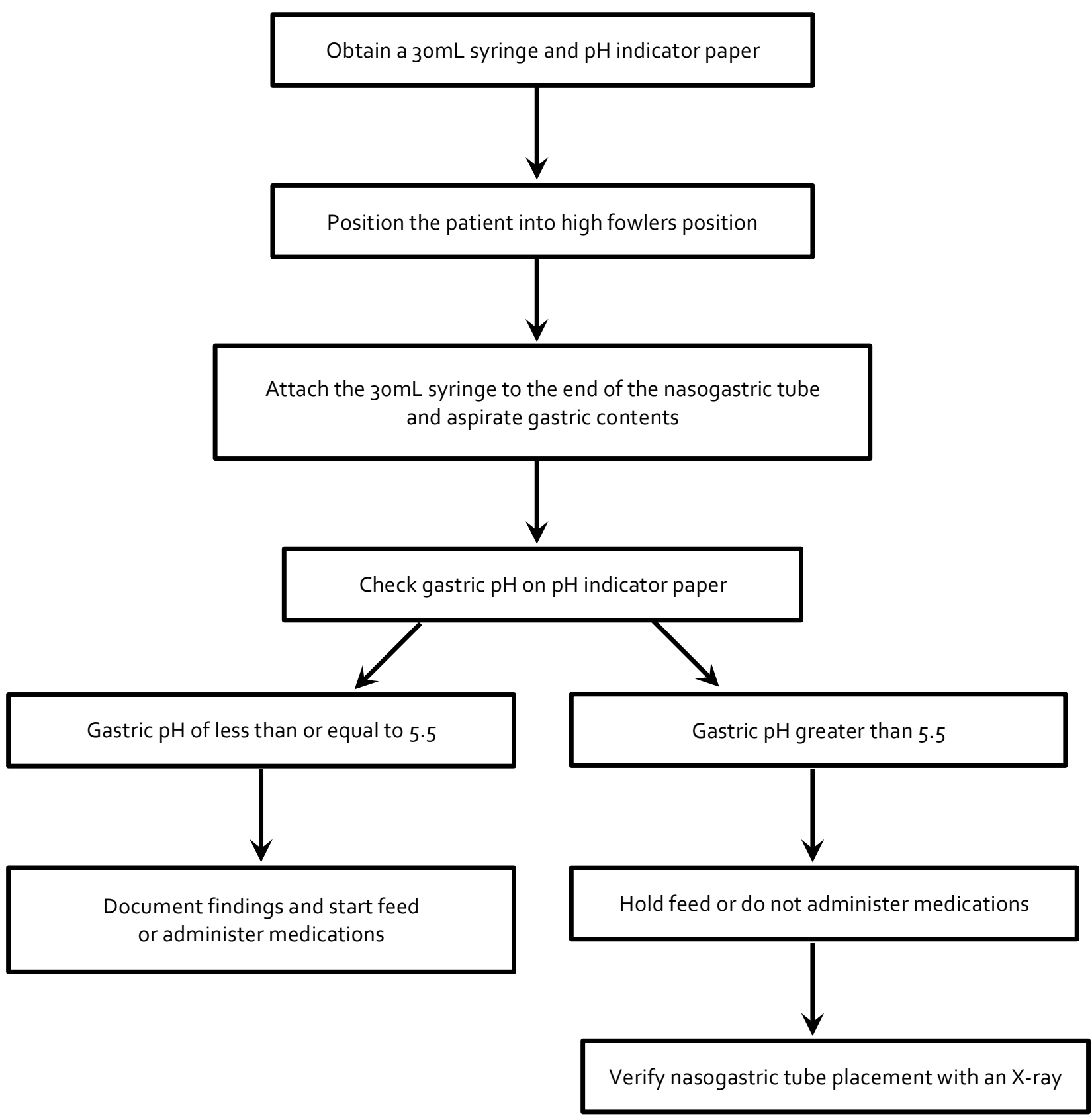

Original diagram created using information from Boeykens et al., (2014), Kozier et al., (2014), and Turgay and Khorshid (2010). 
